\title{
Kritik terhadap Relasi Antagonistis Timur-Barat
}

\author{
Mukhammad Zamzami \\ Universitas Islam Negeri (UIN) Sunan Ampel, Surabaya \\ m.zamzami@uinsby.ac.id
}

\begin{abstract}
The seeds of the clash of thought between the East and the West have become a pin point on the valuable literature of the classical west to take a part on such issues. In short, Hegel's claim on the philosophical history, Darwinism on the evolutional theory and Marxism on the capitalism join in this complex debate. Those three figures play a role in formulating the existence of west civilization with its hegemonic characteristic. The prosperous study on looking another civilization in black-white discourse takes part in growing animosity among civilization. Civilization is a total number of material achievements and thoughts from many generations. Civilization cannot appear from few people for it is a spontaneous design of human being. This article attempts to explore two leading civilizations in the world, Islam and the West. When Islam, which is identical with the East, has tried to observe the West by using Occidentalism as its epistemological approach, polemic and debate become apparent. The tension between the West and the East takes another new volume. This article attempts to elucidate the antagonistic-relationship between the East and the West, the Occidentalism, and epistemological efforts to build the dialogue of civilization.
\end{abstract}

Keywords: Occidentalism, orientalism, Islam, West. 


\section{Pendahuluan}

Nama Samuel Huntington identik dengan wacana Sudâm alHadârah (Benturan Peradaban) meskipun wacana ini sudah diluncurkan oleh Bernard Lewis, melalui artikelnya berjudul "The Roots of Muslim Rage"1 di jurnal Atlantic Monthly, September 1990. Artikel Lewis ini merupakan persiapan untuk menentukan siapa "musuh baru" Barat pasca Perang Dingin.

Huntington kemudian mempopulerkan wacana Lewis. Pemikirannya tentang sudâm al-hadârah khususnya antara Islam dengan Barat masih terus menjadi perbincangan luas. Bukan karena kualitas ilmiah wacana populer tersebut, tetapi karena banyaknya kecocokan antara pemikiran dan saran Huntington dengan perkembangan politik global saat ini. Khususnya, kebijakan politik Barat (terutama AS) terhadap Islam. ${ }^{2}$

Buku terkenal edisi Arabnya, Șuâm al-Hạâarah wa I'âdat Șiyâghat al-Nizâm al-'Alamî, lebih ditujukan sebagai bahan nasihat bagi pengambil kebijakan politik Barat, khususnya AS, dan bukan untuk satu kajian ilmiah dalam ilmu sosial. Titik tolak tesis tersebut adalah "skenario politiknya" yang dibangun atas nama sebuah "peradaban" melalui parameter ilmu historisnya. ${ }^{3}$ Tesis inilah yang nantinya akan ditolak oleh kritikusnya.

Apa yang dibenarkan dari tesis Huntington adalah "krisis identitas" yang dialami oleh orang Islam saat ini. Saat ini seseorang lebih memahami Islam sebagai identitas daripada sebuah agama an sich. Menurut Abdul Karim Soroush bahwa Muslim mempunyai identitas dan

\footnotetext{
${ }^{1}$ Dalam jurnal tersebut Bernard Lewis mengritisi kejayaan peradaban Islam di masa lalu yang juga anti Barat. Baginya Islam menjadikan Barat sebagai "musuh-musuh Tuhan" (a'dâ Allâh). Bahkan sosok Muhammad tidak hanya dikategorikan sebagai Nabi semata, akan tetapi ia juga disebutnya sebagai hâkim muqâtil (hakim dan pembunuh). Lihat Bernard Lewis dan Edward Said, Al-Islâm al-Usûtî fì Wasâil al-I lâm al-Gharbîyah min Wajhat Nadar Amrîkîyah (Beirut: Dâr al-Jayl, 1994), 11.

2 Zakî al-Mîlâd, "Min Ḥiwâr al-Ḥaḍârah ilâ Ta'âruf al-Ḥaḍârât" dalam majalah alKalemah, Vol. 36 (Beirut: Muassasah al-Falâh li al-Nashr wa al-Tawzî’, 2002), 25.

${ }^{3}$ Ibid.
} 
peradaban, itu memang benar, tetapi mereka tidak boleh menggunakan Islam demi kepentingan identitas dan peradaban. Peradaban, menurutnya, adalah konsekuensi yang muncul tanpa diniatkan dari tindakan-tindakan sadar para aktor sosial. Peradaban adalah jumlah total pencapaian materi dan pemikiran dari banyak generasi. Peradaban tidak bisa muncul dari upaya segelintir orang. Sebab, peradaban adalah desain spontanitas. Upaya apa pun yang diniatkan akan berlawanan dengan desain itu. ${ }^{4}$

Artikel ini berusaha melihat dua peradaban, Barat dan Timur, dalam perspektif Timur, di mana ketika peradaban Timur berusaha memberikan anti-tesis terhadap Orientalisme dengan penciptaan studi tandingan berupa Oksidentalisme, hal itu justru menyulut babak baru pertikaian Timur-Barat. Oleh karenanya, upaya mencari "jalan tengah" dalam rangka membangun dialog peradaban penting untuk diaktualkan kembali.

\section{Relasi Antagonistis Barat dan Timur}

Benih-benih benturan pemikiran antara Timur dan Barat sudah menjadi pakem pada khazanah literatur Barat klasik. Sebut saja klaim Hegel $^{5}$ dengan "filsafat sejarah"-nya, Darwinisme dengan "teori evolusi"nya ataupun Marxisme dalam kapitalismenya. Minimal ketiga tokoh tersebut ikut andil dalam merumuskan eksistensi peradaban Barat dengan watak hegemoniknya. ${ }^{6}$ Diakui atau tidak, menjamurnya kajian yang melihat peradaban lain dalam wacana hitam-putih turut andil dalam menyemai benih-benih permusuhan antar peradaban.

\footnotetext{
${ }^{4}$ Abdul Karim Soroush, Menggugat Otoritas dan Tradisi Agama, terj. Muhammad Ali (Bandung: Mizan, 2002), 32.

${ }^{5}$ Hegel dalam hal ini ingin mengeliminir keterkaitan keberadaan filsafat Islam dalam sejarah. Karena baginya, filsafat Islam tidak lebih dari upaya repetisi belaka atas filsafat Yunani dan tidak ada yang khas dari karakteristik keberfilsafannya. Kritik secara komprehensif atas Hegel dikupas dalam kitabnya Husayn Muruwah, Al-Naz'ât alMâdîyah fì al-Falsafah al-'Arabîyah al-Islâmîyah (Beirut: Dâr al-Fârâbî, 2002).

${ }^{6}$ Muhammad Imârah, Fî Fiqh al-Muwâjahah bayn al-Gharb wa al-Islâm (Kairo: Maktabah al-Shurûq al-Dawlîyah, 2003), 63.
} 
Pun demikian dengan khazanah turâth Islam. Setidaknya ada beberapa buku yang mengapresiasi the other (peradaban Barat pada umumnya) sebagai "musuh" abadi. Sebut saja Abû Hasan al-Ash'arî dalam Maqâlât al-Islâmîŷn wa Ikhtilâf al-Musallin, Ibn Hazm al-Andalûsî dalam al-Fișal fî al-Milal wa al-Ahwâ' wa al-Niḥal, al-Shahrastânî dalam alMilal wa al-Niḥal, dan 'Abd al-Qâhir al-Baghdâdî dalam al-Farq bayn alFiraq. ${ }^{7}$ Mereka menciptakan stigma negatif tidak hanya kepada musuhmusuh Islam yang tidak berpaham Abl al-Sunnah wa al-Jamâ'ah, akan tetapi kepada eksistensi agama-agama di luar Islam.

Di sini, terlihat betapa perhatian berlebih kepada perbedaan mazhabiah dapat memancing semangat pertikaian, tidak hanya pada level teologis saja, namun lebih dari itu, klaim-klaim kitab tersebut bisa mempersempit eksistensi keragaman yang ada.

Argumen-argumen teologis yang coba diinisiasikan dari kedua khazanah turâth Islam maupun Barat sama sekali tidak memberikan satu ruang longgar bagi peradaban lain untuk berkembang. Alih-alih merangsang fanatisme atas nama hitam-putih kehidupan, justru menghindari konflik antar-pendapat begitu penting demi memecahkan perbedaan yang ada.

Dalam hal ini, perlunya dialog antar peradaban paling tidak dapat merevitalisasi stereotip dari kedua belah pihak. Seperti yang digagas oleh Ibn Rushd dalam kitabnya, Faṣl al-Maqâl fî mâ bayn al-Sharîab wa al-

\footnotetext{
7 Hasan al-Ṣafâr, "Kayfa Naqra' al-Âkhar" dalam majalah al-Kalemah, Vol. 40 (Beirut: Muassasah al-Falâh li al-Nashr wa al-Tawzî‘, 2003), 11. Seorang muslim fundamentalis bisa memiliki sikap yang apriori terhadap Kristen, karena berasal dari bacaan dan didikan para Kristolog muslim yang mengulas kekurangan, dan kesalahan agama lain. Materi perbandingan agama (muqâranah al-adyân) bukan materi yang mempelajari dan mengenalkan agama-agama lain tetapi sebagai ajakan untuk menyalahkan dan mengkafirkan agama lain. Materi dakwah Islam juga bukan bertujuan mengenalkan ajaran Islam, tapi bersemangat menaklukkan pengikut agama lain. Hal yang sama terjadi dalam sikap antipati terhadap Islam yang berasal dari karya-karya orientalis ekstrem yang mengulang-ulang tesis bahwa Islam adalah agama kekerasan, agama teror, dan agama pedang. Tesis-tesis provokatif itulah yang menyulut kebencian terhadap yang lain dan mengajak manusia itu saling berkonflik, berbenturan dan berperang.
} 
Hikmah min al-Ittisâl, bahwa kebenaran yang datang dari mereka yang berbeda keyakinan (Barat) harus diterima. Sebaliknya, bila mereka membawa kekeliruan/kesalahan, harus dimaafkan dan diperbaiki. ${ }^{8}$

\section{Menegasi Islamphobia dan Xenophobia}

Semenjak tragedi pengeboman 11 September, banyak dari masyarakat non-Islam yang merasa bahwa Islam sebagai agama adalah sebuah potret kusam dikarenakan menjamurnya terorisme di dalamnya.

Ada dua istilah dalam menggambarkan kondisi ketakutan yang terjadi di Timur dan Barat. Pertama, Islamofobia, yang dipahami sebagai ketakutan (Barat) terhadap Islam. Kedua, Xenofobia, yang dipahami sebagai ketakutan terhadap asing seperti ide-ide modernisme, liberalisme, sekularisme, dan pluralisme. Dua jenis phobia ini, bagi sebagian kalangan menjadi sumber utama dari ketegangan internasional saat ini.

Saat teori Clash of Civilization yang digulirkan Samuel Huntington menggegerkan dunia, para cendikiawan Mesir dari unsur Muslim dan Koptik ${ }^{9}$ bersama-sama mereaksinya. Adalah Mîlâd Hannâ yang kemudian menurunkan buku dengan tajuk Qabûl al-Âkhar (Menerima yang Lain) yang kemudian mendapat nobel perdamaian Simon Bolivar Prize 1998.

Modal utamanya adalah budaya qabûl al-âkhar (sikap menerima yang lain). Budaya ini dimulai dari saling memahami dan membuka diri. Nantinya jalan menuju qabûl al-âkhar (the otherness) akan terbuka sendiri. Jika kita telah memiliki budaya qabûl al-âkhar, kita akan dianugerahi hubb al-âkhar (mencintai yang lain). ${ }^{10}$

\footnotetext{
${ }^{8}$ Dikutip dari Maḥmûd Hamdî Zaqzûq, Al-Islâm wa Qaḍââa al-Hiwâr (Kairo: al-Majlis alA'lâ li al-Shu'ûn al-Islâmîyah, 2002), 49.

${ }^{9}$ Koptik (Coptic/al-Qibt) merupakan salah satu sekte Kristen kuno yang sampai di Mesir pada abad pertama masehi di bawah tangan rasul Marcus. Rifấah 'Abd. al-Ḥâmid, AlFiker al-Mașî́ fì 'Asrr al-Masîhî (Kairo: Dâr al-Uhâlî, 2000), 16.

10 Mîlâd Ḥannâ, Qabûl al-Âkhar (Kairo: Maktabah Madbûli, 2000), 93. Suasana kehidupan beragama di Mesir bisa dijadikan panutan. Kerukunan umat beragama menjadi tradisi yang mengakar kuat dalam masyarakat. Tradisi tersebut bersumber pada
} 
Menurut Hạnnâ, kebencian-kebencian tersebut berasal dari "sentimen kolektif" yang berasal dari afiliasi-afiliasi manusia yang beragam: keluarga, suku, agama, bangsa, kepentingan sosial, ekonomi, dan politik. Jika sentimen kolektif itu dilumuri kebencian, maka, ia bisa menjadi amunisi efektif untuk menghancurkan afiliasi-afiliasi lain.

Namun kebekuan, fanatisme dan menganggap afiliasinya paling benar bisa dicairkan jika seseorang mengenal afiliasi-afiliasi lain, dan syukur-syukur bisa memiliki afiliasi yang plural. Seorang pengikut agama tertentu akan dapat menghargai pengikut agama lain, jika ia memiliki perkumpulan lintas agama. Untuk itu, sebuah perkumpulan yang sehat adalah wahana yang mampu mempertemukan keragaman afiliasi dan warna-warni dalam kehidupan manusia. Sederhananya seorang yang fanatik dan kaku, karena persoalan pergaulan saja. Kata pepatah, ibarat katak dalam tempurung. Ia terjebak dan berkutat pada keterbatasan. Untuk itu, ia harus mampu menerobos keluar dari kungkungan tempurung itu untuk menyongsong keragaman lain.

Seperti di Mesir, pola interaksi umat Muslim dan Koptik di sana kerap kali mengundang simpati. Hal itu disampaikan oleh keduanya saat salah satu dari mereka sedang merayakan hari suci. Ketika umat Muslim merayakan Idul Fitri, banyak dari kalangan umat Koptik yang memberikan simpati, baik sekedar memberikan ucapan, memberikan kartu dan karangan bunga tanda selamat, memberikan hadiah, hingga ikut serta hadir dalam perayaan tersebut. Pun ketika umat Koptik merayakan hari raya Natal, tidak sedikit dari umat Muslim yang memberikan simpati serupa.

Justru, yang lebih menjadikannya menarik adalah para pembesar agama kedua belah pihak yang melakukan hal-hal simpatik tersebut. Sayyed Tantâwî, mantan Grand Shaykh al-Azhar, kerap kali bersimpati

karakteristik masyarakat Mesir yang toleran, terbuka, dan kosmopolit. Apalagi Mesir dikenal sebagai melting pot bermacam-macam peradaban: Mesir Kuno (Firaun), YunaniRomawi, Kristen-Koptik, Islam, Laut Mediterania, Arab, dan Afrika. Selain Mesir memiliki julukan yang telah masyhur, umm al-dunyâ (induk peradaban), Mîlâd Ḥannâ menyebut Mesir sebagai akumulasi serpihan-serpihan peradaban (tarâkumât li raqẩi min al-ḥadârât . 
dan menziarahi gereja-gereja Koptik, sama halnya seperti Bapa Sanouda, pucuk pemimpin spiritual umat Koptik Mesir, yang sering berkunjung ke lembaga Al-Azhar dan masjid-masjid.

Bahkan, Shaykh Ṭantâwî membolehkan salat di dalam gereja. Hal ini beliau lakukan berulang kali bersama para ulama al-Azhar lainnya pada waktu-waktu dewan al-Azhar diundang berbuka puasa bersama di gereja-gereja Koptik. Dewan ulama al-Azhar berbuka puasa di gereja tersebut, sekaligus salat berjamaah di sana. Tidak bersama para Babawât tentunya. ${ }^{11}$

Dalam salah satu petikan wawancaranya di mingguan Nehdat Misr, Shaykh Ṭantâwî mengatakan bahwa naḥnu kabanâ' al-wațan al-wâhbid, fa'alaynâ an nahfaz̧a watananâ (kita bersama adalah anak bangsa yang satu, maka wajib bagi kita untuk bersama-sama menjaganya). Shaykh Azhar yang dikenal moderat ini juga menegaskan bahwa perbedaan agama bukan menjadi alasan untuk sebuah perselisihan. Lanâ ma lanâ wa lahum mâ labum, naḥnu abnâ' min al-abb al-wâhid Ibrâhim (bagi kita agama kita dan bagi mereka agama mereka, kita adalah anak-anak dari ayah yang satu, Nabi Ibrahim). ${ }^{12}$

Namun pada kenyataannya, tidak semua peradaban saling memahami nilai-nilai pluralisme agama. Tindakan terorisme yang mengatasnamakan agama menjadi pemicu terjadinya konflik yang berkepanjangan. Padahal, di satu sisi umat Islam juga banyak dirugikan oleh tindakan-tindakan terorisme baik dari segi politik, ekonomi maupun sosial kemasyarakatan. Oleh karena itu, penanggulangan terorisme bukan hanya sebagai tanggung jawab pemerintah saja, namun tanggung jawab masyarakat secara umum. Tidak hanya itu, sebisa mungkin umat Islam mengenalkan wajah Islam yang humanis, toleran dan mempunyai semangat memahami segala perbedaan yang ada. ${ }^{13}$

${ }^{11}$ Lihat www.nehdatmisr.com/, diakses 12 Maret 2005.

12 Ibid.

${ }^{13}$ Maḥmûd Ḥamdî Zaqzûq, Humûm al-Ummah al-Islâmîyah (Kairo: Maktabah al-Usrah, 2001), 37-38. Untuk itu, Zaqzûq mengutip ayat-ayat pluralis dalam QS. Al-Mâidah [5]: 32 dan 33 yang berbunyi: man qatala nafsan bigabyri nafsin aw fasâdin fî al-ard fakannamâ qatala al-nâsa jamî'a ( ) ...an yuqattalù aw yusallabûu aw tuqațta'a aydîhim wa arjulubum min 
Untuk bisa meredam tindakan-tindakan anarkis, umat Islam juga diharapkan bisa mereformasi penafsiran-penafsiran, yang selama ini cenderung mempersempit rahmat Tuhan yang dengan begitu mudahnya melakukan sweeping di luar pemahaman blok-bloknya yang monolitik, yaitu dengan memahamkan peradaban Islam yang melalui sentral ajaranajarannya bisa mengintegrasikan nilai-nilai modernitas juga bagian dari rasa keberagamaannya demi kemajuan peradaban Islam itu sendiri. Dan hal itu sudah pernah sukses dijalani oleh Islam klasik dulu. ${ }^{14}$

Di sisi lain yang tidak kalah penting, Barat harus bisa menghilangkan pandangan bahwa Islam anti demokrasi. Bahkan oleh sebagian pihak, Islam dipandang sebagai "ancaman besar terhadap kegiatan-kegiatan liberal". Menurut Bahtiar Effendi, pendapat semacam ini terbentuk karena adanya pandangan yang monolitik terhadap Islam. Terlebih lagi, pikiran seperti ini hanya merujuk kepada kegiatan sementara aktivis Muslim militan dan radikal, khususnya yang berkembang di Timur Tengah. Sebagaimana dilihat oleh John L. Esposito, "kegiatan-kegiatan yang berbau kekerasan selalu dialamatkan ke Islam daripada ke penafsiran yang salah terhadap Islam, yang dilakukan oleh sementara pihak atau gerakan politik tertentu." Dengan demikian, istilah seperti militan atau radikal Islam "dipakai secara sembarangan, mencakup seluruh pemimpin, negara dan organisasi." Karena sikap yang demikian itu, bagi Huntington, Islam bukan hanya bertolak belakang dengan ide-ide demokrasi, tetapi juga merupakan suatu ancaman bagi peradaban Barat. ${ }^{15}$

Dibutuhkan dialog antar peradaban yang dibangun di atas kesadaran adanya perbedaan, atau kesadaran bahwa potensi-potensi konflik di antara peradaban dirasakan tidak ada gunanya jika terus dipelihara; sebaliknya, ia perlu digantikan dengan sikap saling memahami satu sama lain.

kbilâfin aw yunfầ min al-ard dhâlika lahum khiơyun fî al-dunyâ walahum fì al-âkbirati 'adhâbun 'axim.

14 Ibid., 39-40.

15 Bahtiar Effendi, "Islam dan Demokrasi: Mencari Sebuah Sintesa yang Memungkinkan” dalam Agama dan Dialog Antar Peradaban (Jakarta: Paramadina, 1996), 91. 


\section{Oksidentalisme sebagai Solusi Filsafat Ilmu Baru}

Barangkali, tidak salah ketika Hegel tidak menempatkan filsafat Islam ikut berperan serta dalam memberikan watak filsafat yang khas dalam filsafat sejarahnya. Namun, tidak sepenuhnya tesisnya dibenarkan seandainya ia juga memperinci periodisasi filsafat Islam di Timur, yang diwakili oleh Ibn Sinâ, Al-Fârâbî dan al-Kindî, dan Barat, yang diwakili oleh Ibn Bâjah, Ibn Tufayl, dan Ibn Rushd. Jika kondisi pemikiran filsafat Islam di Timur rentan dengan bias karena ingin mendamaikan filsafat dan agama, maka, keadaan filsafat Islam di Barat benar-benar berbeda. Karena, atas nama filsafat, Ibn Rushd dan para faylasuf Barat lainnya, berusaha memisahkan atribut agama darinya. Inilah filsafat yang sesungguhnya; bahwa ketika agama sama sekali tidak bisa melakukan intervensi terhadap filsafat, itulah 'revolusi pengetahuan' (al-thawrah althaqâfíyab) dalam filsafat. ${ }^{16}$

Dalam rangka mewujudkan kebangkitan Islam, revolusi Islam, dan kesatuan umat, Hasan Hanafî muncul sebagai penerus gagasan Jamâluddîn al-Afghânî dan Muhammad 'Abduh. Stressing pertama yang diinisiasikannya adalah merevitalisasi khazanah Islam klasik dengan pendekatan yang lebih rasional. Baginya, rasionalisme merupakan keniscayaan untuk kemajuan dan kesejahteraan Muslim serta untuk memecahkan situasi kekinian di dalam dunia Islam. ${ }^{17}$ Ia menginginkan bahwa Islam saat ini mengalami fase kebangkitan ketiga, di mana kebangkitan pertama dan kedua adalah masa Nabi saw dan peradaban Islam klasik produktivitas para faylasuf-faylasuf awal Islam. ${ }^{18}$

Kehadiran Hasan Hanafî setidaknya memberikan satu ruang alternatif pemikiran pasca kemunduran filsafat Islam pasca Ibn Rushd. Meneruskan jejak-jejak yang tersisa dari para pendahulunya, Ḥanafi berusaha menjawab problematika Islam dengan gagasan yang lebih

\footnotetext{
${ }^{16}$ Muhammad 'Âbid al-Jâbirî, Naḥnu wa al-Turâth (Beirut: Markaz al-Thaqâfî, 2002), 215.

17 Lihat Hasan Hanafî, Oksidentalisme, Sikap kita terhadap Tradisi Barat Jakarta: Paramadina, 2000), 1-3.

18 Turkî 'Alî al-Rabî'û, "Hal Naḥnu 'alâ A'tâbi Nahḍah 'Arabîyah Thâlithah? Jadal alNahḍah wa al-Suqût fì Khitâbat Ḥanafî wa al-Jâbirî‘ dalam Majalah al-Ijtihâd, vol. 54 (Beirut: Dâr al-Ijtihâd, 2002), 29.
} 
imajiner, salah satunya dalam proyek yang digarapnya adalah teori Oksidentalisme dalam bukunya Muqaddimah fì 'ilm al-Istighrâb.

Istighrâb yang berarti Oksidentalisme adalah upaya mengembalikan posisi Barat dengan Orientalismenya. Oksidentalisme adalah upaya menentang peradaban Barat. Sebelum melangkah pada Oksidentalisme, perlu dibahas dahulu apa yang menjadi pemahaman Hasan Hanafî mengenai tradisi (turâth). Tradisi, menurutnya, bukanlah sekedar barang mati yang telah ditinggalkan orang-orang terdahulu. Menurut Hanafî, tradisi ternyata telah banyak dicemari oleh hegemoni feodalisme dan menjadi kekuatan kekuasaan yang berkedok agama. Sehingga perlu direvitalisasi menjadi kekuatan yang membebaskan.

Tolok ukur yang dipakai Ḥanafî adalah realitas Arab saat ini, dan menurutnya adalah keharusan pemecahannya untuk mengakhiri semua hal yang menghambat perkembangan dalam dunia Islam dan Arab. Tradisi, pada dasarnya tidak bernilai. Kecuali jika ia dapat menjadi sarana yang dapat memberikan teori aksi negara Arab dalam merekonstruksi manusia dan hubungannya dengan Tuhan. Hanafí mensyaratkan revolusi kemanusiaan sebelum melakukan pembangunan lainnya, sebagai langkah awal dalam mewujudkan kehidupan yang manusiawi. ${ }^{19}$ Bahkan, dengan berjilid-jilid buku yang menjadi bagian dari proyeknya adalah usaha untuk mengubah kata "Tuhan" menjadi kata "Manusia".

Proyek Ḥanafî dimaksudkan untuk merekonstruksi, menyatukan, dan menginterpretasikan seluruh ilmu peradaban Islam berdasarkan kebutuhan modern untuk dijadikan sebagai ideologi manusia, untuk menuju kesempurnaan hidup. Hanafî juga bermaksud merekonstruksi tradisi kebudayaan Barat yang dicirikannya sebagai kebudayaan murni historis, di mana wahyu Tuhan tidak dijadikan sebagai sentral peradaban, ${ }^{20}$ karena sudah digantikan oleh rasio. ${ }^{21}$ Hanafî sedang

19 Ḥasan Hanafî, Al-Turâth wa al-Tajdîd, Mawqifunâ min al-Turâth al-Qadìm (Beirut: AlMuassasah al-Jâmi’ah li al-Dirâsah wa al-Nashr wa al-Tawzî', 1992), 11.

${ }^{20}$ Issa J. Boullata, Dekonstruksi Tradisi: Gelegar Pemikiran Arab Islam (Yogyakarta: LKiS, 2001), 62 . 
mendekonstruksi bangunan pemikiran Islam klasik yang mati fungsi peradabannya, di samping juga mendekonstruksi klaim-klaim universalitas dan hegemoni wacana yang dilakukan Barat, melalui pemikiran dan kebudayaan westernis. Pandangan objektif dan kritis dalam pemikiran Ḥasan Ḥanafî adalah bagaimana agenda "Oksidentalisme" menjadi kekuatan wacana penyeimbang dalam melihat Barat dan upaya westernisasi.

Seperti dijelaskan Ḥasan Hanafi, Oksidentalisme adalah wajah lain dan tandingan bahkan berlawanan dengan Orientalisme. Orientalisme melihat ego (Timur) melalui the other, maka Oksidentalisme bertujuan mengurai simpul sejarah yang mendua antara ego (al-anâ) dengan the other (al-âkhar), dan dialektika antara kompleksitas inferioritas (murâkab al-naqs) pada ego dengan kompleksitas superioritas (murâkab al'ugmâ) pada pihak the other. Orientalisme lama adalah pandangan ego Eropa terhadap the other non-Eropa, subjek pengkaji terhadap objek yang dikaji. Di sini terjadi superioritas Barat dalam melihat Timur. Hal demikian dibalikkan dengan Oksidentalisme, yang tugasnya yaitu mengurai inferioritas sejarah hubungan ego dengan the other, menumbangkan superioritas the other Barat, yang awalnya menjadikan Arab sebagai objek kajian, ${ }^{22}$ dengan menjadikannya sebagai objek yang dikaji, dan melenyapkan inferioritas kompleks ego dengan menjadikannya sebagai subjek pengkaji, ${ }^{23}$ seperti pada awalnya. ${ }^{24}$ Hanya saja Oksidentalisme kali ini dibangun di atas ego yang netral dan tidak berambisi merebut kekuasaan, dan hanya menginginkan pembebasan. Ia juga tidak ingin mendiskreditkan kebudayaan lain, dan hanya ingin mengetahui keterbentukan dan struktur peradaban Barat. Seperti diklaim

${ }^{21}$ Yumnâ Ṭarîf al-Khûlî, "Jadal al-Anâ wa al-Âkhar fî Mashrû' al-Turâth wa al-Tajdîd” dalam Jadal al-Anâ wa al-Âkhar: Qirâ'ah Naqdîyah fî Fiker Hasan Hanafî̀ (Kairo: Madbûlî al-Ṣaghîr, 1997), 183.

22 Ibid.

${ }^{23}$ Hanafi, Oksidentalisme, 25-26.

${ }^{24}$ Al-Khûlî, "Jadal al-Anâ, 183. 
oleh Hasan Hanafî, ego Oksidentalisme lebih bersih, objektif, dan netral dibandingkan ego Orientalisme. ${ }^{25}$

Pemikiran Hasan Hanafî juga dilandasi oleh penafsiran secara hermeneutik terhadap teks keagamaan (tradisi keilmuan Islam lama) agar didapatkan pemahaman yang hidup dalam memberikan kontribusi bagi pembebasan. Oksidentalisme, dengan demikian, bertujuan untuk menumbuhkan kesadaran kolektif umat Islam dalam membaca tradisinya sendiri dan tradisi the other. Pemikiran dia juga bermuatan rasional, karena jika masih menggunakan baju konservatisme agama maka tradisi tidak akan berbicara apa-apa. Teks itu adalah barang mati, yang hidup adalah makna dan interpretasi baru. Tugas umat Islam adalah bagaimana menghidupkan teks dalam tradisi itu menjadi relevan dan berguna bagi kondisi saat ini.

Oksidentalisme adalah sebentuk solusi yang coba ditawarkan Hanafi dalam menjawab kegundahan umat Islam terhadap superioritas Barat. Tidak semua masyarakat Arab menerima ide-ide Hanafi karena apa yang digagasnya adalah sebentuk propaganda dalam membentuk peradaban Islam menjelma menjadi the special one melalui super egosentrisnya.

\section{Kritik terhadap Oksidentalisme Hasan Hanafi}

Karya-karya Hasan Hanafì tidak luput dari pembacaan para kritikusnya, terutama berkenaan dengan teori Oksidentalismenya. Para pengkritik merasa bahwa 'dialektika ego dan the other (jadal al-anâ wa alakhar) adalah rangkaian upaya mengambil alih posisi superioritas peradaban Barat. Superioritas tersebut tidak akan pernah direbut dari Barat kecuali Barat mengalami fase kemunduran dan ketiadaan. Hanya karena ego Arab-Islam saat itu menjadi kerangka historis utama the other Barat untuk maju bukan berarti 'kebangkitan dan keterpurukan' (satu

${ }^{25}$ Ibid., 29. 
peradaban tertentu) menjadi kesadaran yang harus dijalani untuk membunuh peradaban yang lain. ${ }^{26}$

Ini berarti, hubungan antar peradaban dalam kacamata Oksidentalisme tidak lain hanya akan memicu benturan peradaban baru, bukan sebuah dialog peradaban seperti banyak diharapkan. Hal ini karena upaya melepaskan diri dari keterikatan antar peradaban coba didekonstruksinya atas nama sebuah kebangkitan peradaban Islam. ${ }^{27}$

Dalam meramu teori al-Turâth wa al-Tajdìd dalam kerangka Oksidentalismenya, Hanafî mendasari teorinya dengan tiga pendekatan: reformasi bahasa, meaning, dan realitas. Reformasi bahasa berarti mengorientasikan bahasa yang lebih aktual sebagai ganti dari bahasa doktrinal. Maka, lebih ideal menggunakan bahasa 'ideologi' ketimbang 'agama', 'insan kamil' ketimbang 'Allah'. Adapun pembaharuan dalam bentuk meaning adalah usaha membaca tradisi melalui reduksi transendental (melalui perasaan). Bagi Hanafí, perasaan itu lebih penting daripada akal, lebih cermat ketimbang hati, dan lebih agung daripada kesadaran. Dalam hal ini, terlihat bahwa Hanafî membangun kerangka reformasi tahap kedua dengan pendekatan fenomenologi ${ }^{28}$ Husserl. Sedangkan reformasi realitas adalah usahanya mengembalikan realitas budaya pada tempatnya sembari memberikan prioritas kepada interaksi

\footnotetext{
${ }^{26}$ al-Rabî̀û, "Hal Nahnuu”, 330-331.

27 al-Khûlî, "Jadal al-Anâ", 183.

28 Untuk mematok suatu dasar yang tidak dapat dibantah bagi semua ilmu pengetahuan. Husserl memakai apa yang disebut metode fenomenologi. Metode ini mulai dengan reduksi (pengurungan) ganda: (a) reduksi eidetik dan (b) reduksi fenomenologis. Reduksi eidetik menangguhkan keyakinan akan adanya ego, adanya kegiatan persepsi dan adanya keyakinan mengenai objek. Reduksi eidetik ini hanya mementingkan esensi objek-objek tetapi dalam bentuk konkretnya yang purna. Dalam reduksi fenomenologi ketidakbergantungan objek-objek juga dalam tanda kurung untuk sementara Husserl memahami fenomenologi sebagai suatu analisa deskriptif serta introspektif mengenai kedalaman dari semua bentuk kesadaran dan pengalaman langsung: religius, moral, estetis, konseptual serta indrawi. Lihat Lorens Bagus, Kamus Filsafat Jakarta: PT Gramedia Pustaka Utama, 2002), 236.
} 
'ubudîyah. ${ }^{29}$ Baginya, fenomenologi adalah sebuah aliran iluminasi rûhŷyah dan idealis. ${ }^{30}$

Dalam akhir buku al-Turâth wa al-Tajdîd, Hanafî ingin meresolusi kejayaan peradaban Islam yang baru dengan cara merekonstruksi disiplin keilmuan Islam: Teologi, Ușûl al-Fiqh, Filsafat, dan Tasawuf. ${ }^{31}$ Keempat disiplin keilmuan tersebut mempunyai landasan historis-epistemologis yang bisa dikembalikan kejayaannya. Ini berbeda dengan peradaban Barat, karena baginya watak Barat sifatnya evolutif, tidak mempunyai nilai historis dalam mengembangkan sistem keilmuan yang paten. Ini terbukti penyebutan marxisme dan historisme dengan sosialisme, kemudian diganti dengan humanisme. ${ }^{32}$

Fenomenologi adalah akhir dari citra perkembangan intelektual Barat dalam membangun kesadaran Eropa, namun bagaimana cara Ḥanafi membangun kesadaran baru untuk peradaban baru Islam kalau ia sendiri mengumumkan berakhirnya 'kesadaran' itu sendiri. ${ }^{33}$

Akhirnya, Oksidentalisme bukanlah sebuah solusi jitu dalam menghadapi ancaman peradaban Barat. Kalaupun mengubah tatanan egosentrisme orientalis ke oksidentalis bisa mendamaikan dua kutub Barat dan Timur, maka tesis Hanafî masih bisa dipertimbangkan. Namun, melihat paradigma yang dibangunnya hanya akan mendestruksi ego dan peradaban lain, maka apa artinya sebuah peradaban dalam kacamata antropologi yang senantiasa harus berkorespondensi secara ekstensif?

\footnotetext{
${ }^{29}$ Maḥmûd Amîn al-'Âlim, "Al-Istighrâb: Mashrû‘ Ḥasan Ḥanafî al-Ḥaḍarî” dalam Jadal al-Anâ wa al-Âkhar: Qirâ’ah Naqdîyah fî Fikr Hasan Hanafî̀ (Kairo: Madbûlî al-Ṣaghîr, 1997), 164.

${ }^{30}$ Ibid.

${ }^{31}$ Proyek-proyek tersebut sebagian besar sudah terealisir dalam bentuk buku. Sebut saja Min al-Naql ilâ al-Ibdẩ (Filsafat); Min al-'Aqîdah ilâ al-Thawrah (Teologi); Min al-Naṣs ilâ al-Wâqi' (Usûl Fikih). Min al-Fanâ' ilâ al-Baqâ' (Tasawuf).

32 al-'Âlim, "Al-Istighrâb”, 167.

33 Ibid., 173-174.
} 


\section{Penutup}

Sesungguhnya, hiwwâr al-ḥadârah dibangun di atas etos perdamaian yang seharusnya menjadi tujuan pendidikan dalam setiap agama. Tidak dapat dipungkiri bahwa usaha untuk mengenal dan memahami posisi pihak lain, secara eksplisit akan mendekatkan kita pada tujuan perdamaian. Pemahaman terhadap pihak lain ini harus menyentuh pada wilayah pemikiran dan keyakinan mereka. Terutama mengingat bahwa seluruh kegiatan praksis mereka berpijak pada dua wilayah tersebut.

Di sisi lain, pemahaman terhadap mereka juga akan memperluas cakrawala pengetahuan kita, selain akan dapat memperdalam pengetahuan tentang wujud kemanusiaan universal. Pada gilirannya, hal ini akan membuka jalan ke arah pemahaman bersama, dialog yang efektif, dan dorongan untuk saling membantu mewujudkan perdamaian di dunia tempat kita hidup.

\section{Daftar Pustaka}

'Âlim (al), Maḥmûd Amîn. "Al-Istighrâb: Mashrû' Ḥasan Ḥanafî alHaḍarî, dalam Jadal al-Anâ wa al-Akhar: Qirâab Naqdîyah fî̀ Fikr Hasan Hanafî. Kairo: Madbûlî al-Saghîr, 1997.

Bagus, Lorens. Kamus Filsafat. Jakarta: PT Gramedia Pustaka Utama, 2002.

Boullata, Issa J. Dekonstruksi Tradisi: Gelegar Pemikiran Arab Islam. Yogyakarta: LKIS, 2001.

Effendi, Bahtiar. "Islam dan Demokrasi: Mencari Sebuah Sintesa yang Memungkinkan" dalam Agama dan Dialog Antar Peradaban. Jakarta: Paramadina, 1996.

Hanafi, Hasan. Al-Turâth wa al-Tajdìd, Mawqifunâ min al-Turâth al-Qadìm. Beirut: Al-Muassasah al-Jâmi'ah li al-Dirâsah wa al-Nashr wa alTawzî', 1992.

Oksidentalisme, Sikap Kita Terbadap Tradisi Barat. Jakarta: Paramadina, 2000. 
Hâamid (al), Rifâ'ah 'Abd. Al-Fiker al-Mașri fî̀ 'Așr al-Masîĥ̉. Kairo: Dâr alUhâlî, 2000.

Hannâ, Mîlâd. Qabûl al-Âkhar. Kairo: Maktabah Madbûlî, 2000.

Imârah, Muhammad. Fî Fiqh al-Muwâjahah Bayn al-Gharb wa al-Islâm. Kairo: Maktabah al-Shurûq al-Dawlîyah, 2003.

Jâbirî (al), Muhammad 'Âbid. Naḥnu wa al-Turâth. Beirut: al-Markaz alThaqâfî, 2002.

Khûlî (al), Yumnâ Ṭarîf. “Jadal al-Anâ wa al-Âkhar fî Mashrû' al-Turâth wa al-Tajdîd", dalam Jadal al-Anâ wa al-Akkhar: Qirâ'ah Naqdîyah fì Fiker Hasan Hanafî, Kairo: Madbûlî al-Saghîr, 1997.

Milad, Zaki. "Min Hịiâr al-Ḥaḍârah ilâ Ta'âruf al-Ḥaḍâât" dalam majalah al-Kalemah, vol. 36. Beirut: Muassasah al-Falâh li al-Nashr wa al-Tawzî̀, 2002.

Muruwah, Husayn. Al-Nażah al-Mâdîyah fì al-Falsafah al-'Arabîyah alIslâmîyah. Beirut: Dâr al-Fârâbî, 2002.

Rabî̀u (al), Turkî 'Alî. "Hal Naḥnu 'alâ A'tâbi Nahḍah 'Arabîyah Thâlithah? Jadal al-Nahḍah wa al-Suqût fî Khitâabay Hanafî wa alJâbirî́" dalam Majalah al-Ijtihâd, edisi 54. Beirut: Dâr al-Ijtihâd, 2002.

Șafâr (al), Hasan. "Kayfa Naqra' al-Âkhar" dalam majalah al-Kalemah, vol. 40. Beirut: Muassasah al-Falâh li al-Nashr wa al-Tawzî', 2003.

Soroush, Abdul Karim. Menggugat Otoritas dan Tradisi Agama, terj. Muhammad Ali. Bandung: Mizan, 2002.

Zaqzûq, Maḥmûd Ḥamdî. Humûm al-Ummah al-Islâmîyah. Kairo: Maktabah al-Usrah, 2001. - Al-Islâm wa Qadâyâ al-Hịinâr. Kairo: Al-Majlis al-A'lâ li alShu'ûn al-Islâmîyah, 2002.

www.nehdatmisr.com/. 